\title{
Plant breeding for disease resistance in the age of effectors
}

\section{Richard Oliver}

Published online: 16 December 2008

(C) Springer Science + Business Media B.V. 2008

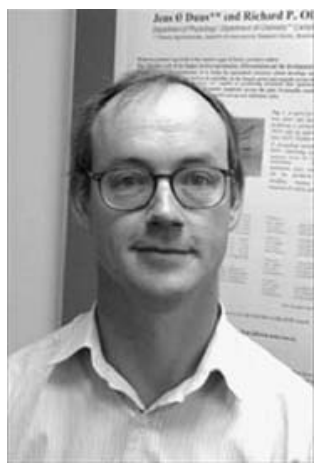

Richard Peter Oliver born in the United Kingdom in 1958. Prof. of Physiological and Molecular Plant Pathology, Murdoch U., Australia, and Director of the Australian Centre for Necrotrophic Fungal Pathogens (ACNFP). BSc (1979) and PhD (1982) in Biochemistry from the U. of Bristol, UK, with a thesis focussing on the enzyme protochlorophyllide oxidoreductase. EMBO fellow at the Carlsberg Laboratory (Denmark) with Prof.

R. Oliver $(\square)$

Australian Centre for Necrotrophic Fungal Pathogens,

Murdoch University, FHS,

Perth, WA 6150, Australia

e-mail: roliver@murdoch.edu.au
Diter von Wettstein researching the molecular biology of the barley plastid genome 1982-84. Lectureship at the U. of East Anglia was his first introduction to plant pathology and he concentrated on developing molecular tools for fungal pathogens (especially Cladosporium fulvum) and researching disease resistance in Arabidopsis to fungal pathogens, such as powdery mildew (1984-96). Returned to the Carlsberg Laboratory as Prof. and Head of the Physiology Dept. and continued research on C. fulvum as well as developing genomic tools for barley powdery mildew (1996-2000). A short stay at Zeneca (UK) was followed by a move to Australia (2000) to start the ACNFP with the goal of understanding foliar necrotrophic pathogens, especially Stagonospora nodorum. Since 2000 the centre has developed full scale omics tools for $S$. nodorum including the genome sequence, transcriptomics, proteomics and metabolomics. Publications: 120 refereed papers, 180 other papers, edited two books. Founding senior editor of Molecular Plant Pathology, senior editor of Molecular Plant-Microbe Interactions. Numerous editorial board and ad-hoc editing roles. Current Research: Pathogenic mechanisms of Pleosporalean fungi, disease resistance in Medicago truncatula, genetics mapping in legumes.

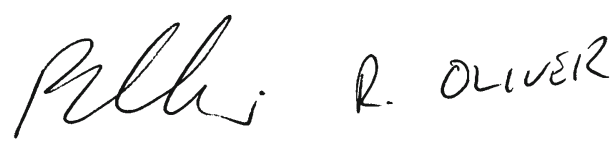




\section{Plant breeding for disease resistance in the age of effectors}

Plant breeding and plant pathology have long been interdependent, sibling disciplines. Furthermore, plant breeding for disease resistance has always been a central plank in our quest for effective crop protection. Nonetheless, the fact that E.C. Large's lament (Large 1940) - first published in 1940 - still rings very true, makes us wonder whether we have really made much progress.

"So much spraying and dusting of the crops with chemical mixtures! So much particularized research into the ways of destructive insects and parasitic fungi and nameless viruses! So much elaborate crossing and back-crossing between strains of agricultural plants in attempts to breed varieties that might escape some, but never all, of the parasites that lie in wait for them! Infinite patience for every small achievement; control measures that were often costly, or that demanded closely-knit collaboration between farmers, research workers and governments to make them effective!

"Was there no simpler and more direct way of raising healthy crops? No general safeguard or panacea against all the murraines to which they were heir?" (Large 1940)

Plant breeding is not concerned only with disease resistance, but also with local adaptation, resistance to abiotic stresses, quality and yield. Similarly, while plant pathologists often regard genetic disease resistance as the best means of attack, agronomic practices - crop hygiene, rotations and tillage - and chemical control are also effective and necessary components of productive agricultural systems.

In this editorial, I will examine the role of plant pathologists in plant breeding and how it could more closely reflect the advances made, particularly in molecular aspects of plant pathology.

The traditional role of the plant pathologist in breeding can be said to be encapsulated in the work of William Farrer (McIntosh 2007), who combined the role of breeder and pathologist. His success in combining good bread-making qualities with rust resistance (in wheat) laid the foundation of Australian grain productivity. That this was done in the period
1895 to 1906 , prior to the rediscovery of Mendel, is truly remarkable. The selection of rust-resistant germplasm and lines was entirely phenotypic and was based primarily on selecting early maturing lines that set seed and filled prior to major infections. As rust is such a visible disease and because it was being treated as a single entity, it was not hard to detect rustresistant wheat.

The role of the pathologist in selecting and evaluating disease-resistant lines by phenotypic selection has continued to this day, but with steeply increasing complexity. Foliar biotrophic pathogens, such as the rusts and powdery mildews, represent the easiest pathogens to visualize but they also exist in the highest number of physiologic races. Hence the number of assessments has to be multiplied by the number of races. The age of the plant also affects the response, again multiplying the complexity and costs. In regions with high disease pressure, it can be challenging to create a control uninfected plant without the use of pesticides, many of which are known to have other confounding effects. Finally, while visual symptoms are straightforward to score, the link between degree of symptoms and yield or quality penalty is rarely well established.

Foliar biotrophic pathogens pose serious challenges, but these are outweighed by the difficulty in assessing disease to necrotrophic foliar pathogens such as those caused by Dothideomycete fungi (Friesen et al. 2008a) and even more so to pathogens of the stem, crown and root caused by genera such as Fusarium, Verticillium and Rhizoctonia. Many of these pathogens are now known to exist in a myriad of races, further adding to the difficulty. In many cases, resistance is weak and quantitative so that assessments have to be done on populations of host plants, rather than individuals.

Many efforts have been made to replace or supplement visual scores of disease with methods that measure the biomass of pathogens within diseased tissue (Fox 1993). Such proxy biomass methods have attempted to use chitin, ergosterol or mannitol in the past. Nowadays methods based either on antibodies (particularly for viruses) or nucleic acids enjoy some success. Various polymerase chain reaction (PCR) techniques can be used to detect and quantify pathogen genomic DNA (and occasionally RNA (Van Esse et al. 2007)) and thereby quantify the pathogen biomass (Nicholson et al. 2002; Nicholson 
et al. 2003; Oliver et al. 2008). PCR offers ultimate sensitivity, specificity and quantification. If the genetic basis of the difference between races of a pathogen is known, PCR can be used to distinguish such races (Andrie et al. 2008). It is also capable of simultaneously assessing all the diseases being suffered by a plant (Bezuidenhout et al. 2006; Fountaine et al. 2007; Mumford et al. 2006; Schena et al. 2004; Tooley et al. 2006). This is impossible with visual assessment, where many visual symptoms overlap and interfere.

Despite these challenges, phenotypic disease resistance has achieved major advances, particularly in the foliar biotroph area (Park 2008).

Such phenotypic assessments formed the entire picture for almost 100 years until the 1980s, when the use of host genetic molecular markers (originally isozymes, but now overwhelmingly DNA polymorphisms - single nucleotide polymorphisms, microsatellites, transposon variants, etc.) became a possibility (Tanksley et al. 1989). Here the goal for the pathologist was to associate disease resistance with a particular allele of a segregating molecular genetic marker. Such molecular markers would then be used as a proxy for disease resistance in breeding programs. The role of the pathologist was not so different, being to score plants for disease resistance according to which molecular markers they carried. Thus the same arguments that applied to phenotypic whole-plant scoring applied to scoring of genetic markers. Hence, most advances were made in relation to markers for foliar biotrophic pathogens and least for root-infecting pathogens. There was also a largerthan-expected investment phase required to achieve the marker density and utility for each crop. Large and coordinated investments were needed and these seem to have been easier to achieve in the private sector than in the public sector depressed by crop over-production in Europe and elsewhere. As a result, the use of markers in breeding is still in its infancy in most crops. Even when used, it is well applied only to those pathogens that are best assessed by traditional phenotypic methods.

It is 25 years since the first pathogen avirulence gene was cloned and Flor's gene-for-gene hypothesis was confirmed (Staskawicz et al. 1984). We now have a plethora of such pathogen molecules from all pathogen types. In recent years the confusing term avirulence has been dropped and replaced by the neutral term “effector" (Kjemtrup et al. 2000). Effectors also include so-called PAMPs (pathogen-associated molecular patterns; Nürnberger and Brunner 2002), host-specific toxin molecules (typically produced by fungi in the Pleosporales, Friesen et al. 2008a), and non-specific toxins produced by many (all perhaps except the haustorial biotrophic) pathogens. It is also 15 years since the first resistance gene was cloned and together with several hundred R-genes we also have uncovered details of PAMP receptors, guard proteins and defence response pathway genes (Jones et al. 1994; SchulzeLefert 2004; Shirasu et al. 1999; Staskawicz et al. 1984; Staskawicz et al. 1995).

It is axiomatic that the disease incidence and severity is a function of all the interactions between a pathogen's effectors and the host receptors and the response that is induced. Hence, we can now recognize that we can use expressed pathogen genes or synthesized pathogen effectors to select responsive or nonresponsive host germplasm. The use of such effectors would allow the dissection of complex quantitative traits into a series of qualitative (or at least more precisely quantifiable) molecular interactions. Selection of such germplasm brings the power of the reductionist approach to crop breeding. It would also allow the weighing of breeders' goals that conflict with disease resistance into series of quantifiable decisions.

Therefore the role of pathologist in plant breeding can now be seen as isolating, synthesizing and deploying pathogen effectors. Where are these effectors to be found? The effectors that were first found were from bacteria with, for the time, facile genetic systems. The first fungal effectors to be discovered were hostspecific toxins recovered from culture filtrates and the Cladosporium fulvum avr and ecp products recovered from apoplastic washing fluids (Bolton et al. 2008; De Wit and Spikman 1982). Pathogen genome sequencing, which is now a normal rather than an extraordinary budget item, is the primary data that reveals pathogen effector molecules. In our work, sequencing the $S$. nodorum genome revealed the presence of ToxA (Friesen et al. 2006; Hane et al. 2007; Liu et al. 2006). This is one of at least a dozen host-specific toxins that operate in the wheat $S$. nodorum pathosystem (Friesen et al. 2008b). Expressed ToxA can be used as a simple tool to select non-responsive and quantitatively more resistant germplasm.

Until and unless all a pathogen's effector suite is cloned, expressed and deployed, it will be necessary 
to use the living pathogen to assess host germplasm. However, this can be refined by the use of strains that lack the expression of the known effectors and thus represent the pathogenic potential of the remaining effectors. In most cases, however, such strains will be transgenic and will thus require the use of containment facilities in most jurisdictions despite being less virulent than the wild type.

Molecular plant pathology is 25 years old but few are celebrating the milestone because the practical benefits that have accrued are not overwhelming. This can change now as we bring the immense amount of details known about model systems and facile organisms to bear on the major pathogens of the major crops, both of temperate and tropical regions. This requires that the tools of genomics are used on these pathogens and the results are adopted and exploited by pathologists working alongside the breeders.

Acknowledgments Work in my laboratory is supported mainly by the Australian Grains Research and Development Corporation. The ideas in this editorial have been developed in conversations and based on the work of many colleagues but I would especially mention Peter Solomon and Tim Friesen.

\section{References}

Andrie, R. M., Schoch, C. L., Hedges, R., Spatafora, J. W., \& Ciuffetti, L. M. (2008). Homologs of ToxB, a hostselective toxin gene from Pyrenophora tritici-repentis, are present in the genome of sister-species Pyrenophora bromi and other members of the Ascomycota. Fungal Genetics and Biology, 45, 363-377.

Bezuidenhout, C. C., Prinsloo, M., \& Van der Walt, A. M. (2006). Multiplex PCR-based detection of potential fumonisin-producing Fusarium in traditional African vegetables. Environmental Toxicology, 21, 360-366.

Bolton, M. D., Van Esse, H. P., Vossen, J. H., De Jonge, R., Stergiopoulos, I., Stulemeijer, I. J. E., et al. (2008). The novel Cladosporium fulvum lysine motif effector Ecp6 is a virulence factor with orthologues in other fungal species. Molecular Microbiology, 69, 119-136.

De Wit, P., \& Spikman, G. (1982). Evidence for the occurrence of race and cultivar-specific elicitors of necrosis in the intercellular fluids of compatible interactions of Cladosporium fulvum and tomato. Physiological Plant Pathology, 21, 1-11.

Fountaine, J. M., Shaw, M. W., Napier, B., Ward, E., \& Fraaije, B. A. (2007). Application of real-time and multiplex polymerase chain reaction assays to study leaf blotch epidemics in barley. Phytopathology, 97, 297-303.

Fox, R. T. V. (1993). Principles of Diagnostic Methods in Plant Pathology. Wallingford, UK: CAB.
Friesen, T. L., Faris, J. D., Solomon, P. S., \& Oliver, R. P. (2008a). Host-specific toxins: effectors of necrotrophic pathogenicity. Cellular Microbiology, 10, 1421-1428.

Friesen, T. L., Stukenbrock, E. H., Liu, Z., Meinhardt, S., Ling, H., Faris, J. D., et al. (2006). Emergence of a new disease as a result of interspecific virulence gene transfer. Nature Genetics, 38, 953-956.

Friesen, T. L., Zhang, Z., Solomon, P. S., Oliver, R. P., \& Faris, J. D. (2008b). Characterisation of the interaction of a novel Stagonospora nodorum host-selective toxin with a wheat susceptibility gene. Plant Physiology, 146, 682-693.

Hane, J. K., Lowe, R. G. T., Solomon, P. S., Tan, K. C., Schoch, C. L., Spatafora, J. W., et al. (2007). Dothideomycete-plant interactions illuminated by genome sequencing and EST analysis of the wheat pathogen Stagonospora nodorum. Plant Cell, 19, 3347-3368.

Jones, D., Thomas, C., Hammond-Kosack, K., Balintkurti, P., \& Jones, J. (1994). Isolation of the tomato cf-9 gene for resistance to Cladosporium fulvum by transposon tagging. Science, 266, 789-793.

Kjemtrup, S., Nimchuk, Z., \& Dangl, J. L. (2000). Effector proteins of phytopathogenic bacteria: bifunctional signals in virulence and host recognition. Current Opinion in Microbiology, 3, 73-78.

Large, E. C. (1940). The advance of the fungi. Republished 2003 with a new introduction by Karen-Beth G. Scholthof, Paul D. Peterson, and Clay S. Griffith. St. Paul, MN, USA: American Phytopathological Society.

Liu, Z., Friesen, T. L., Ling, H., Meinhardt, S. W., Oliver, R. P., Rasmussen, J. B., et al. (2006). The Tsn1-ToxA interaction in the wheat-Stagonospora nodorum pathosystem parallels that of the wheat-tan spot system. Genome, 49, 1265-1273.

McIntosh, R. A. (2007). From Farrer to the Australian cereal rust control program. Australian Journal of Agricultural Research, 58, 550-557.

Mumford, R., Boonham, N., Tomlinson, J., \& Barker, I. (2006). Advances in molecular phytodiagnostics - new solutions for old problems. European Journal of Plant Pathology, 116, 1-19.

Nicholson, P., Turner, A. S., Edwards, S. G., Bateman, G. L., Morgan, L. W., Parry, D. W., et al. (2002). Development of stem-base pathogens on different cultivars of winter wheat determined by quantitative PCR. European Journal of Plant Pathology, 108, 163-177.

Nicholson, P., Chandler, E., Draeger, R. C., Gosman, N. E., Simpson, D. R., Thomsett, M., et al. (2003). Molecular tools to study epidemiology and toxicology of fusarium head blight of cereals. European Journal of Plant Pathology, 109, 691-703.

Nürnberger, T., \& Brunner, F. (2002). Innate immunity in plants and animals: emerging parallels between the recognition of general elicitors and pathogen-associated molecular patterns. Current Opinion in Plant Biology, 5, 318-324.

Oliver, R. P., Rybak, K., Shankar, M., Loughman, R., Harry, N., \& Solomon, P. S. (2008). Quantitative disease resistance assessment by real-time PCR using the Stagonospora nodorum-wheat pathosystem as a model. Plant Pathology, $57,527-532$.

Park, R. F. (2008). Breeding cereals for rust resistance in Australia. Plant Pathology, 57, 591-602.

Schena, L., Nigro, F., Ippolito, A., \& Gallitelli, D. (2004). Realtime quantitative PCR: a new technology to detect and 
study phytopathogenic and antagonistic fungi. European Journal of Plant Pathology, 110, 893-908.

Schulze-Lefert, P. (2004). Knocking on heaven's wall: pathogenesis of and resistance to biotrophic fungi at the cell wall. Current Opinion in Plant Biology, 7, 377-383.

Shirasu, K., Nielsen, K., Piffanelli, P., Oliver, R., \& SchulzeLefert, P. (1999). Cell-autonomous complementation of mlo resistance using a biolistic transient expression system. Plant Journal, 17, 293-299.

Staskawicz, B., Dahlbeck, D., \& Keen, N. (1984). Cloned avirulence gene of Pseudomonas syringae pv. glycinea determines race-specific incompatibility on Glycine max (L) Merr. Proceedings of the National Academy of Sciences of the United States of America, 81, 60246028.
Staskawicz, B., Ausubel, F., Baker, B., Ellis, J., \& Jones, J. (1995). Molecular genetics of plant disease resistance. Science, 268, 660-667.

Tanksley, S., Young, N., Paterson, A., \& Bonierbale, M. (1989). RFLP mapping in plant breeding: new tools for an old science. Bio/Technology, 7, 257-264.

Tooley, P. W., Martin, F. N., Carras, M. M., \& Frederick, R. D. (2006). Real-time fluorescent polymerase chain reaction detection of Phytophthora ramorum and Phytophthora pseudosyringae using mitochondrial gene regions. Phytopathology, 96, 336-345.

Van Esse, H. P., Bolton, M. D., Stergiopoulos, I., De Wit, P. J. G. M., \& Thomma, B. P. H. J. (2007). The chitin-binding Cladosporium fulvum effector protein Avr4 is a virulence factor. Molecular Plant-Microbe Interactions, 20, 1092-1101. 